PAUlina OKŁa

UKSW WARSZAWA

ORCID: 0000-0002-7251-8672

\title{
POPULARYZACJA PISMA ŚWIĘTEGO W RZECZYWISTOŚCI CYFROWEJ. ZARYS PROBLEMATYKI
}

Proklamacja Słowa Bożego domaga się nieustannego poszukiwania nowych dróg i form docierania do współczesnego człowieka. Wynika to z samej natury Słowa, które nie może ulec skrępowaniu (por. 2Tm 2, 9). W obliczu postępującej laicyzacji, w szeroko rozumianym duszpasterstwie i ewangelizacji media spełniają rolę współczesnej ambony ${ }^{1}$. Kościół, wychodząc na cyfrowe peryferie, podejmuje troskę o „owce, które poginęły” (por. Mt 10, 6), o ludzi żyjących „na pustyni”".

Celem niniejszego artykułu jest ukazanie idei realizacji nakazu misyjnego poprzez popularyzowanie Pisma Świętego w rzeczywistości cyfrowej. Prezentowane studium jest efektem refleksji naukowej nad dostępnymi źródłami oraz własnej obserwacji środowisk społecznościowych. Wyznaczony cel zostanie zrealizowany w trzech kolejnych paragrafach. Pierwszy z paragrafów to ukazanie źródła obowiązku głoszenia Słowa Bożego, wypływającego ze Starego i Nowego Testamentu. Druga część poświęcona jest charakterystyce rzeczywistości, w jakiej dokonuje się popularyzacja Pisma Świętego. Trzeci punkt to przedstawienie proponowanych form popularyzacji Pisma Świętego w polskiej rzeczywistości cyfrowej.

\section{Przywilej i obowiązek głoszenia Słowa Bożego}

Pismo Święte stanowi dla chrześcijan źródło i podstawę wyznawanej wiary. Wraz z Tradycją składa się na ,jeden, święty depozyt Słowa Bożego powierzony

\footnotetext{
1 Por. A. Domaszk, Środki komunikacji społecznej w nauczaniu Kościoła i misji ewangelizacyjnej, „Seminare” 34 (2013), s. 94.

2 Benedykt XVI stwierdził: „Wiele osób żyje na pustyni. Pustynia posiada kilka form. Istnieje pustynia nędzy, pustynia głodu i pragnienia, pustynia porzucenia, samotności i zniszczonej miłości, (...) pustynia ciemności Boga, wypalenia duszy, gdzie zanika świadomość godności człowieka. Trzeba tam pójść". Por. Benedykt XVI, Homilia wygłoszona w czasie Mszy świętej inaugurującej pontyfikat, 24.04.2005, w: https://www.wprost.pl/swiat/75928/homilia-benedykta-xvi.html [dostęp 5.05.2020].
} 


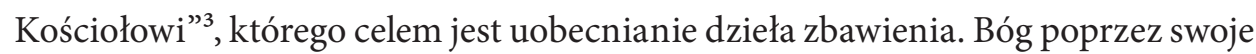
Słowo powołał do istnienia świat, wciąż zachowuje go i nie przestaje dawać świadectwa o sobie samym ${ }^{4}$. Apogeum komunikacji Boga z ludźmi stanowi osoba Chrystusa. Jezus jest najpełniejszym Słowem, jakie skierował do całego stworzenia Bóg Ojciec. Poprzez Syna każdy zaproszony jest do podjęcia dialogu ze Stworzycielem. Duch Święty zaś wspomaga osobę w odczytywaniu poprzez poznane Słowo celu swojego istnienia, odkrywania własnej tożsamości, rozpoznawania osobistego powołania i misji oraz wewnętrznie zobowiązuje do dawania świadectwa życiem o tym, co się widziało, słyszało i czego doświadczało (por. 1J 1, 1).

\section{a. Stare Przymierze}

Historia biblijna już od pierwszych kart Starego Testamentu ukazuje różnorakie drogi i sposoby, jakimi posługiwał się Bóg w celu nawiązania kontaktu osobowego z człowiekiem. Relacja pomiędzy Ojcem a powołanym spośród pogan Abrahamem stanowi wzór procesu budowania zaufania i pewności wiary opartej na słuchaniu Bożego Słowa. Już wtedy następuje zapowiedź o przekazaniu Bożego orędzia wszystkim ludom ziemi (por. Rdz 12, 3b). Po nawiązaniu głębokiej relacji „partnerzy" dialogu ze Stworzycielem, idąc za Jego wezwaniem i poleceniem, stawali się sługami Słowa. Świadectwo ich wiary było pierwszą płaszczyzną oddziaływania względem tych, których spotykali ${ }^{5}$.

Stopniowo Bóg poszerzał kręgi, gdzie docierało Jego Słowo. Poprzez doświadczenie exodusu Naród Bożego Wybrania stał się znakiem pośród pogan (Wj 19, 4-6) ${ }^{6}$. Wybranie to nie dokonało się jednak przez wzgląd na indywidualną świętość, z którą - jak wiadomo - Izraelici miewali poważne problemy (por. Wj 15, 24nn; 16, 2nn; 17, 2nn; 32, 1nn), lecz poprzez obecność Boga pośród ludu. Pomimo silnej tendencji izolacyjnej, jaką obserwujemy w postępowaniu Izraelitów, od początku znana im była idea powszechności zbawienia ${ }^{7}$.

Wybierając często to, co „słabe w oczach świata” (1Kor 1, 27), Bóg powoływał sędziów i proroków, aby nieśli Jego orędzie już nie tylko do Izraelitów, lecz także szeroko rozumianych pogan. Należy tu wymienić chociażby proroka Izajasza czy Jonasza wraz z głoszonymi przez nich proroctwami (np. Iz 19, 19-25). O przypadkach swoistej otwartości świadczy obecność w narodzie Izraela prozelitów, tzw. „bojących się Boga”, czy istnienie „dziedzińca pogan” w Świątyni Jerozolimskiej.

3 DV 10; por. D. Kwiatkowski, Głoszenie Słowa Bożego misją Kościoła w świecie na podstawie adhortacji apostolskiej Benedykta XVI Verbum Domini, „Teologia Praktyczna” 17 (2016), s. 93-106. 4 Por. DV 3.

5 Por. T. Nawracała, Bóg kieruje słowo do Abrahama. Możliwości poznania drugiej Osoby boskiej w Starym Testamencie, „Studia Theologica Varsaviensia” 2/51 (2013), s. 211-229.

6 Por. M. Gołębiewski, Objawienie Boga w Starym Testamencie, „Studia Theologica Varsaviensia” 23/2 (1985), s. 19-43; J. Daniélou, Święci poganie Starego Testamentu. Pisma wybrane, Kraków 2013.

7 Por. S. Szymik, Biblia o powszechności zbawienia, „Forum Teologiczne” 5 (2004), s. 7-21. 
Także w rodowodzie Jezusa z Nazaretu znajdujemy postaci spoza kręgu żydowskiego, takie jak Rachab (kobieta z Kanaanu) czy Rut Moabitka. Należy jednak podkreślić, iż nie było to zjawisko powszechne.

Ekonomia zbawienia, ukazywana na kartach Starego Testamentu, przedstawia Bożą pedagogię, realizowaną względem człowieka. Głoszone Słowo oraz zaproszenie do bliskości i dialogu ma charakter uniwersalny ${ }^{8}$. Celem wszystkich działań związanych z przekazywaniem Bożego orędzia była zapowiedź i przybliżenie najpełniejszego wypowiedzenia się Boga poprzez osobę Jezusa - Logosa.

\section{b. Nowe Przymierze}

W prologu Ewangelii św. Jana Syn Boży nazwany jest Słowem, które „było u Boga i Bogiem było Słowo" (J 1, 1). Misją Syna Bożego było zaniesienie Dobrej Nowiny do wszystkich narodów. Pomimo swoistego pierwszeństwa pochodzących z Izraela Jezus nie zamyka ani siebie, ani tym bardziej głoszonego Słowa jedynie dla potomków Abrahama. Wielokrotnie mamy do czynienia ze scenami biblijnymi, gdzie spotyka się On z Samarytanami; jako wzór postępowania ukazuje postaci pogan (np. Naaman, królowa Saby, wdowa z Sarepty Sydońskiej). Podróżując, odwiedzał pogańskie okolice, takie jak Tyr, Sydon czy miejscowości Dekapolu, łamiąc dotychczasowe stereotypy.

Podczas publicznej działalności Jezus gromadził wokół siebie uczniów, którym przekazał kontynuację swojej misji. Wezwanie „Idźcie zatem i uczyńcie uczniami wszystkie narody" (Mt 28, 19) rozpoczyna oficjalny kierunek działania Kościoła i przekazywania Słowa Bożego ${ }^{9}$. Nakaz misyjny Jezusa znajduje opis swojej kontynuacji w Dziejach Apostolskich. Realizacji zadania proklamacji Słowa zawsze towarzyszy natchnienie Ducha Świętego, który kieruje drogami uczniów (por. Dz 16, 7).

Należy podkreślić także, iż głoszenie prawd Ewangelii za pośrednictwem przypowieści oraz odwoływanie się do obrazów z codziennego życia ówczesnych ludzi stanowiło poszukiwanie najlepszego sposobu dostosowania treści ewangelicznych do odbiorcy. Odkrywanie nowych możliwości przekazu w żadnej mierze nie ograniczało mocy orędzia. Polecając głoszenie Dobrej Nowiny o zbawieniu wszystkim narodom, Chrystus pozostawił chrześcijanom obowiązek dawania świadectwa wiary słowem i życiem ${ }^{10}$.

\footnotetext{
8 Por. LG 1, 13, 19; I. Bokwa, Magisterium Kościoła o powszechnej nadziei zbawienia, „Studia Theologica Varsaviensia" 30 (1992) 2, s. 165-171.

9 Por. M. Bednarz, Powszechność zbawienia w świetle Nowego Testamentu, w: S. Budzik, Z. Kijas (red.), Uniwersalizm chrześcijaństwa a pluralizm religii, Tarnów 2000, s. 31-51.

10 Por. W. Ostafiński, Orędzie głoszone przez Jezusa Chrystusa, w: H. Sławiński (red.), Głosimy Pana Jezusa Chrystusa. Treść przepowiadania, Kraków 2017, s. 67-86.
} 


\section{c. Przykład św. Pawła}

Osobie św. Pawła zawdzięczamy teologiczne uporządkowanie i uargumentowanie obowiązku proklamacji Słowa Bożego wszystkim narodom. Stał się on prekursorem poszukiwania nie tylko nowego języka, ale i właściwego sposobu przekazy wania orędzia. Dzięki apostołowi nastąpiła swoista transpozycja z języka stosowanego przez „rybaków” do języka filozofów, jakim posługiwał się Paweł. Wprowadzenie do przekazu Ewangelii pojęć greckich poszerzyło zakres potencjalnych odbiorców ${ }^{11}$.

Zaprowadzony przez Ateńczyków na Areios pagos ${ }^{12}$ Paweł wykorzystał zaistniałą sytuację, aby głosić Słowo Boże kolejnym środowiskom. Mając świadomość, iż jego słuchacze nie pochodzą z kręgu znającego treść i symbolikę Starego Przymierza, zrezygnował $\mathrm{z}$ argumentacji biblijnej. Wystosowując odpowiednie argumenty (w tym odwołanie się do greckiej poezji i filozofii), w żadnej mierze nie zniekształcał ewangelicznej prawdy ${ }^{13}$. Punktem wyjścia była sytuacja egzystencjalna słuchaczy ${ }^{14}$.

Perspektywa, iż nie odniósł on znacznego sukcesu, powinna pomóc w uświadamianiu, iż troska o głoszenie orędzia Słowa Bożego współczesnym ludziom nie ma na celu osiągnięcia wzrostu liczby wyznawców. Należy pamiętać, że rzucane ziarno Słowa pada na różnorodne „gleby serca” (por. Mt 13, 1-8). Sługa Słowa Bożego ma wykazy wać zaangażowanie w dzieło głoszenia Ewangelii dzisiejszemu społeczeństwu, pamiętając o zasadzie, że to Bóg jest dawcą wzrostu (por. 1Kor 3, 7).

$\mathrm{Na}$ aktualność postawy apostoła i obowiązek wkraczania na współczesne areopagi wskazał Benedykt XVI: „Świat cyfrowy, dostarczający środków, które dają niemal nieograniczoną zdolność wyrazu, pozwala w nowy sposób odczytywać Pawłowe wezwanie: „Biada mi [...], gdybym nie głosił Ewangelii” (1Kor 9, 16). Wraz z upowszechnianiem się nowych technologii obowiązek głoszenia nie tylko wzrasta, ale staje się coraz bardziej naglący i wymaga bardziej umotywowanego i skutecznego zaangażowania"15.

Podsumowując powyżej przedstawione kwestie, misja głoszenia Słowa Bożego znajduje swoje źródło już w Starym Przymierzu. Nakaz misyjny, nadany przez Jezusa Jego uczniom jest jednocześnie obowiązkiem i przywilejem dla głoszącego. Proklamacja Dobrej Nowiny jest oparta na międzyludzkiej relacji. Wypełniając to posłannictwo, należy poszukiwać coraz to nowszych form i sposobów głoszenia

\footnotetext{
11 Por. S. Szymik, Biblia o powszechności zbawienia, dz. cyt., s. 19-20.

12 Oryg. „Aresowa skała”. Ówcześnie było to miejsce spotkań Wysokiej Rady, gdzie dokonywały się liczne dyskusje. Por. D.H. Stern, Komentarz żydowski do Nowego Testamentu, Warszawa 2017, s. $448 \mathrm{nn}$.

13 Por. P.C. Bosak, Paweł, w: tenże, Leksykon wszystkich postaci biblijnych, Kraków 2015, s. 1180-1197.

14 Por. D. Pawson, Klucz do Biblii, Warszawa 2016, s. 475-478.

15 Benedykt XVI, Orędzie na 44. Światowy Dzień Środków Społecznego Przekazu, http://bit.ly/sk16-7 [dostęp 5.05.2020].
} 
Słowa. Owoc podjętej posługi zależy w głównej mierze od postawy wrażliwości odbiorcy.

\section{Charakterystyka rzeczywistości cyfrowej}

Papież Benedykt XVI, charakteryzując współczesną rzeczywistość cyfrową, pisał: „Z Ewangelią w dłoniach i w sercu należy powtarzać, że jest to także czas, w którym wciąż trzeba torować drogi prowadzące do Słowa Bożego (...). Nowe środki umożliwiają nawiązanie kontaktu z wyznawcami wszystkich religii, z niewierzącymi i przedstawicielami różnych kultur, toteż duszpasterstwo w świecie cyfrowym musi pamiętać także o tych, którzy nie wierzą, są zniechęceni, a w sercu mają pragnienie Absolutu i nieprzemijającej prawdy. Podobnie jak prorok Izajasz, który zdołał wyobrazić sobie dom modlitwy dla wszystkich narodów (por. Iz 56, 7), czy i my nie możemy uznać, że w Sieci - podobnie jak na „dziedzińcu pogan” w Świątyni Jerozolimskiej - może znaleźć się miejsce również dla tych, którzy Boga jeszcze nie znają?”16. Zatem pośród różnych cech opisujących współczesnego człowieka na pierwszy plan wychodzą: brak wiary, wszechobecna cyfryzacja oraz medializacja życia człowieka.

\section{a. Brak wiary}

Od wielu lat jesteśmy świadkami potęgującej się laicyzacji, czego naturalnymi konsekwencjami są malejące liczby uczęszczających na niedzielne Msze Święte. $\mathrm{Z}$ roku na rok zmniejsza się odsetek dzieci i młodzieży biorących udział w szkolnej lekcji religii. Jej uczestnicy, choć mają pewną wiedzę dotyczącą wiary i moralności, przejawiają zdecydowaną trudność $\mathrm{w}$ budowaniu relacji z Bogiem. Wzrasta liczba związków niesakramentalnych i rozwodów. Kwestie ochrony życia od poczęcia do narodzin, eutanazji, promocja środowisk LGBT silnie antagonizują społeczeństwo. Wzrasta szeroko pojęta wrogość do chrześcijaństwa ${ }^{17}$.

Ponadto obserwujemy znaczący spadek autorytetu rodziców oraz zniszczenie więzi budowanych w rodzinie, która jest pierwszym środowiskiem odpowiedzialnym za wychowanie do świadomej wiary. Tym samym brak jest budowania relacji z Bogiem w oparciu o Słowo Boże. Coraz więcej osób zmaga się z konsekwencjami różnorodnych dysfunkcji, doświadczanych w środowisku rodzinnym. Wartości,

\footnotetext{
16 Tamże.

17 Por. Instytut Statystyki Kościoła Katolickiego SAC, Annuarium Statisticum Ecclesiae in Polonia, Warszawa 2020; J. Mariański, Praktyki religijne w Polsce - ciagłość i zmiana, „Roczniki Nauk Społecznych” 2/38 (2010), s. 55-86; A. Napiórkowski, Współczesny sekularyzm a teologia sekularyzacji jako wyzwania dla wiary, „Teologia Praktyczna” 14 (2013), s. 17-39.
} 
jakimi kieruje się człowiek, są niepewne i często zmienne, co doprowadza do zagubienia ${ }^{18}$.

Swoiste przebodźcowanie utrudnia skupienie i słuchanie, będące ważnymi elementami w odbiorze Pisma Świętego. Negatywne przedstawianie Kościoła poprzez wyśmiewanie wartości, manipulowanie wypowiedziami jego członków i przedstawicieli, a także „wewnętrzne rozdarcie” oraz niewyjaśnione konflikty obniżają wiarygodność przesłania ewangelicznego i osłabiają podejmowane działania ewangelizacyjne ${ }^{19}$.

Pewnego rodzaju nieufność do tego, co związane z życiem wiarą, wydaje się stanowić rodzaj poprawności światopoglądowej, kształtowanej przez media ${ }^{20}$. Współczesny człowiek łatwo przyjmuje wszelkie komunikaty publikowane w Internecie, uznając prezentowane treści za prawdziwe. Tematy dotyczące wspólnoty Kościoła często oparte są na przesłankach pochodzących z wątpliwych źródeł. Wszystkie te kwestie znacznie obniżają pozycję medialną Kościoła w rzeczywistości cyfrowej, utrudniając tym samym wiarygodność przekazu Słowa Bożego poprzez członków wspólnoty wierzących. Efektem widocznym w postawie współczesnego człowieka jest coraz rzadsze poszukiwanie osobowej relacji z Bogiem. Tym samym brak jest przełożenia na decyzje i postępowanie poznanych poprzez Pismo Święte prawd ewangelicznych. Naturalne pragnienie bliskości ze Stwórcą jest zagłuszane poprzez medialny chaos i zamieszanie. Człowiek wykazuje zagubienie, często nie umiejąc określić, kim jest ani dokąd zmierza.

\section{b. Cyfrowa społeczność}

W przestrzeni cyfrowej mamy do czynienia z coraz doskonalszymi technologiami i nieustannie wzrastającymi możliwościami komunikacji za ich pośrednictwem. Obserwując przestrzeń medialną, na ogół można zauważyć, że głoszone poglądy wielokrotnie prezentują idee sprzeczne z ewangelicznymi. Sytuacja ta przypomina dyskusje podejmowane na starożytnym areopagu. Wątpliwość wzbudza jednak ich poziom merytoryczny. Konstruowane wypowiedzi zdają się przeakcentowane emocjonalnością. Coraz bardziej powszechne staje się zjawisko manipulacji i wyolbrzymiania przedstawianych treści. Środowisko wydaje się silnie opiniotwórcze i mocno krytyczne w wydawaniu ocen ${ }^{21}$. Występuje promocja seksualizacji oraz przemocy. Spadek odpowiedzialności, beztroska i brak konsekwencji podejmowanych działań

\footnotetext{
18 Por. E. Węgrzyn-Jonek, Rozważania o wychowaniu. W poszukiwaniu teoretycznych podstaw koncepcji wychowawczej szkoly, Warszawa 2014.

19 Por. A. Adamski, Refleksja teologiczna nad naturą Kościoła rzymskokatolickiego a jego wizerunek medialny, w: B. Bogołębska, M. Worsowicz (red.), Dialog wiary z nauka i kultura, Łódź 2013, s. 41-60.

20 Por. M. Karczewski, Niektóre sposoby medialnego „wyjaśniania” Biblii, „Studia Elbląskie” 9 (2008), s. $89-100$.

21 Por. A. Lepa, Ewangelizować areopag mediów, „Studia Warmińskie” 39 (2002), s. 333-345.
} 
są owocem częstej anonimowości, jaką można zachować w Internecie. Pojawiają się problemy w rozróżnianiu świata realnego od wirtualnego, czego dowodem są liczne uzależnienia od rozmaitych form użytkowania przestrzeni medialnej ${ }^{22}$.

Osoby korzystające ze środków społecznego przekazu tworzą swoistą społeczność. Każdy z jej członków przynależy do konkretnej grupy zawodowej, różni się stanem cywilnym, preferencjami politycznymi, wiekiem czy wykształceniem. Następuje zmniejszenie dystansu społecznego oraz przestrzennego. W związku z występującą różnorodnością użytkowników Internetu forma przekazu treści Pisma Świętego również powinna być zróżnicowana tak, by dotrzeć do jak najszerszego grona odbiorców. Stanowi to duże wyzwanie dla poszukiwania nowych dróg proklamacji Słowa Bożego.

Analizując możliwości, jakie płyną z coraz powszechniejszego korzystania z mediów, należy wziąć pod uwagę kwestie przenikliwości i wzrastającego dostępu oraz skutecznego wpływu na odbiorców. Mamy do czynienia z nowym stylem życia, cywilizacją obrazu ${ }^{23}$. Należy jednak stwierdzić, iż nie jest to jedynie negatywny obraz rzeczywistości cyfrowej. Jest to środowisko o wielkim potencjale duszpasterskim ${ }^{24}$.

Orędzie Słowa Bożego ma nie tyle wykorzystywać współczesne media, używając ich jako narzędzi, co przenikać całą tę rzeczywistość chrześcijańskim sposobem bycia i myślenia ${ }^{25}$. „Analiza zjawiska dominacji obrazu i marginalizacji słowa prowadzi (...) do wniosku, że trwa obecnie wielka wojna obrazu ze słowem. Niektórzy nawet twierdzą, że jest to wojna obrazu ze Słowem, które stało się ciałem i zamieszkało wśród nas $(\mathrm{J} 1,14)^{\prime 26}$.

Podejmując refleksję nad aktualną sytuacją, warto przytoczyć papieskie słowa, wyrażające niepokój i zatroskanie o przyszłość świata. Św. Jan Paweł II w orędziu dotyczącym przestrzeni wirtualnej skierował pytanie, czy „Z owej galaktyki obrazów i dźwięków wyłoni się twarz Chrystusa i da się słyszeć Jego głos?”27.

\footnotetext{
22 Por. T. Goban-Klas, P. Sienkiewicz, Społeczeństwo informacyjne: szanse, zagrożenia, wyzwania, Kraków 1999.

${ }^{23}$ Por. EN 42; T. Prauzner, Wpływ nowoczesnych mass mediów na osobowość człowieka, „Edukacja-Technika-Informatyka" 1 (2010) 2, s. 46-50.

24 Por. J.M. Nogowski, Duszpasterstwo w Polsce wobec mass mediów, „Civitas et Lex” 3 (2016) 11, s. 7-14.

25 Por. RM 37; ChL 44; Franciszek, Homilia podczas Mszy św. w kaplicy Domu św. Marty, 6.03.2014, w: http://bit.ly/sk16-8 [dostep 1.05.2020].

26 A. Lepa, Ewangelizować areopag mediów, dz. cyt., s. 339.

27 Jan Paweł II, Orędzie na 36. Światowy Dzień Środków Społecznego Przekazu, nr 3, w: www.paulus. org.pl/231,36-sdssp-jan-pawel-ii-2002 [dostęp 1.07.2020]; por. J. Kloch, Wypłynąć na głębię: stosowanie technologii informatycznych i Internetu w Kościele w myśli Jana Pawła II, „Studia Elbląskie” 7 (2006), s. 239-245.
} 


\section{c. Homo medialis}

Podejmując się misji popularyzacji Pisma Świętego w rzeczywistości cyfrowej, należy wziąć pod uwagę potrzeby oraz możliwości potencjalnego odbiorcy. „Homo medialis (...) to nowy typ człowieka, myślącego wyobrażeniami zmysłowymi, rozproszonego i przewrażliwionego, którego namiętności łączą się z emocjonalnymi obrazami. Nie potrafi on skupić się na aktualnej pracy ani na głębszej refleksji. Podświadomie nawet dąży do zmiany wrażeń, tracąc często kontrolę nad sferą sensoryczną. To człowiek, który nie dochodzi do prawdy o rzeczywistości, ale pozostaje tylko na jej medialnym obrazie"28.

Współczesne społeczeństwo jest obecnie w momencie pewnego rodzaju przełomu antropologicznego, czego konsekwencje należy koniecznie uwzględniać, podejmując się misji głoszenia orędzia ewangelicznego w mediach społecznościowych $^{29}$. Członkowie rzeczywistości cyfrowej często przejawiają postawę pasywną, niewymagającą od nich większego wysiłku intelektualnego ${ }^{30}$. W przypadku młodszych użytkowników obserwujemy przygnębienie czy wręcz złość z powodu braku połączenia z siecią bądź brakiem urządzenia mobilnego. Homo medialis często nawet nie zauważa, w jaki sposób kształtuje i zmienia swoje poglądy, postawy, uczucia i preferencje pod wpływem przekazów medialnych. Dla wielu z nich jest to jedyne źródło wiedzy o świecie, w tym także wiedzy o Piśmie Świętym i Kościele ${ }^{31}$. W tej perspektywie jeszcze silniejsze wydaje się wezwanie do budowania właściwego obrazu wspólnoty eklezjalnej w rzeczywistości cyfrowej oraz jej zaangażowania w podejmowane działania o charakterze ewangelizacyjnym.

Współczesny odbiorca jest wyczulony na sposób, w jaki dokonuje się komunikowanie przekazywanych treści. Zarówno w świecie realnym, jak i w świecie wirtualnym głoszenie Ewangelii wymaga formy przekazu, naznaczonej dyskrecją oraz szacunkiem dla każdego człowieka ${ }^{32}$.

\footnotetext{
${ }_{28}$ M. Dróżdż, Duchowość w sieci, w: https://currenda.diecezja.tarnow.pl/archiwum/2007/01/art-18.php [dostęp 5.05.2020].

29 Por. A. Adamski, Człowiek zmediatyzowany, „Studia Theologica Varsaviensia” 1 (2017), s. 59-73; A. Andrzejewska, J. Bednarek, S. Ćmiel (red.), Człowiek w świecie rzeczywistym i wirtualnym, Józefów 2013.

30 Por. D. Fołtyn, Człowiek wobec mediów. Media wobec człowieka, „Zeszyty Formacji Katechetów” 9 (2020), s. 9-18.

31 Por. D. Kubicka, Rozwój człowieka w zmediatyzowanym świecie, w: M. Turska-Kielar (red.), Studia nad rozwojem i wychowaniem: w osiemdziesiata rocznice powstania Zakładu Psychologii Rozwojowej $i$ Wychowawczej na Uniwersytecie Jagiellońskim, Kraków 2009, s. 77-86.

32 Por. M. Dróżdż, Głosić Dobrą Nowinę na cyfrowych areopagach, w: M. Legan (red.), Bramy prawdy i wiary. Benedykt XVI o mediach, Kraków 2016, s. 111-126.
} 


\section{Formy popularyzacji Słowa Bożego w rzeczywistości cyfrowej}

Jak popularne w czasach starożytnych dyskusje, których miejscem był Areios pagos, były przestrzenią poszukiwania prawdy, tak również dziś media są szansą dla rozwoju przekazu orędzia Słowa Bożego. Świat użytkowników mediów społecznościowych jest miejscem dawania świadectwa chrześcijańskiego ${ }^{33}$. Niepodważalną kwestią jest fakt, iż często są to środowiska trudne i nieprzychylne słowom oraz treściom ewangelicznym. Obowiązek dawania wiarygodnego świadectwa jest tym bardziej potrzebny. Poprzez osobistą życzliwość, jaką prezentują chrześcijanie, będący użytkownikami współczesnych mediów, otwierają się kolejne drogi dla Kościoła i głoszonego Słowa.

Należy podkreślić, obserwując dotychczasowe sposoby popularyzacji Pisma Świętego, iż istnieje poszukiwanie nowych dróg przekazu, adekwatnych do wcześniej przedstawionej charakterystyki członków rzeczywistości cyfrowej. Aby grupa odbiorców orędzia biblijnego powiększała się, koniecznym jest, by w obliczu dynamicznego rozwoju technologii forma prezentowała wysoki poziom profesjonalności.

Według raportu przedstawionego przez IMAS International ${ }^{34}$ codzienną styczność z Biblią ma jedynie 3,4\% Polaków, natomiast 19,2\% czyta ją przynajmniej raz w roku. Raport przedstawia także informację, że około 50\% czytelników podczas kontaktu ze Słowem Bożym korzysta z różnych form dostępnych online. Analizując powyższe dane, istnieje nagląca potrzeba docierania z orędziem Słowa Bożego do współczesnego świata. Biorąc pod uwagę powszechność korzystania z rozwijającej się technologii oraz coraz większą jej atrakcyjność, należy wykorzystać jej potencjał w popularyzacji przekazu biblijnego. Dla wielu użytkowników może to stanowić jedyny kontakt z Pismem Świętym. Pomocą w realizacji tego zadania są poszczególne narzędzia, zrzeszające ludzi przebywających w rzeczywistości cyfrowej ${ }^{35}$.

\section{a. Portale społecznościowe (Facebook, Instagram)}

Popularyzacja Pisma Świętego pośród użytkowników mediów społecznościowych dokonuje się najczęściej za pośrednictwem obrazu, choć nie jest to jedyna forma przekazu. Wielu użytkowników tworzy oddzielne profile, gdzie zamieszcza poszczególne fragmenty ksiąg świętych, przygotowanych w formie atrakcyjnej grafiki ${ }^{36}$. Należy tu wymienić cieszące się największym zainteresowaniem takie

\footnotetext{
33 Por. T. Kopiczko, Środki społecznego przekazu pomoca w prowadzeniu do wiary, „Studia Katechetyczne" 10 (2014), s. 163-173; W. Misztal, Cyberprzestrzeń i mass media sprzymierzeńcem duchowości?, „Analecta Cracoviensia” 44 (2012), s. 179-190.

${ }^{34}$ Por. IMAS International, Raport z badania „Jak czytamy Pismo święte?”, Wrocław 2018.

35 Por. K. Peszko, Popularność mediów społecznościowych wśród różnych generacji, „Marketing i Zarządzanie" 4/45 (2016), s. 361-370.

36 Uwagi metodologiczne: w celu odszukania stosowanych w tym paragrafie danych użyto wyszukiwarek w kolejno omawianych portalach. Wybór prezentowanych profilów dokonuje się pod względem największej liczby obserwujących użytkowników. Dane na dzień 15.05.2020.
} 
inicjatywy jak: „Najlepsze cytaty z Pisma Świętego” (ponad 75 tys. obserwujących), „Słowo Boże na dziś” (ponad 65 tys.), „Twoja Biblia” (ponad 37 tys.), „Czytam Słowo Boże” (ponad 32 tys.), „Czytam Pismo Święte” (ponad 13 tys.), „Tajemnice Pisma Świętego” (ponad 13 tys.), „Słowo Boże w sieci” (ponad 11 tys.), „Biblijni.pl” (ponad 10 tys.). Pod każdym zamieszczanym postem zawierającym treści biblijne istnieje możliwość komentowania oraz udostępniania. Nierzadko także dochodzi pomiędzy użytkownikami do internetowych dyskusji. To również poszerza zakres oddziaływania treści na innych, głównie grona znajomych korzystającego z wyżej wymienionych miejsc użytkownika.

Oprócz ogólnodostępnych profili występują grupy publiczne, mające na celu wzajemne ubogacanie się refleksjami z podejmowanych medytacji. Przykładem takiej społeczności jest „Pismo Święte/czytania na każdy dzień” (ponad 4 tys. członków). Ta forma zdecydowanie poszerza możliwość głębszej wymiany doświadczeń z duchowego spotkania ze Słowem Bożym. Problemem może być jednak szybkie powielanie błędów, wynikających ze słabej znajomości właściwych metod interpretacji Słowa Bożego.

Zapis medytacji bądź homiletycznego wyjaśnienia znaczenia orędzia biblijnego jest obecny także na profilach osobistych biblistów polskich, biskupów, kapłanów i katechetów oraz ośrodków rekolekcyjnych. Ta forma popularyzacji pomaga właściwie interpretować symbole i prostować dotychczas powielane błędy interpretacyjne ${ }^{37}$. Wciąż jednak liczba podejmowanych tego typu działań nie jest zadowalająca.

Ponadto istnieją miejsca mające na celu zaproszenie do nauki języków biblijnych. Przykładem jest tutaj profil „Hebrajski biblijny - początkujący” (ponad 1,6 tys. członków), gdzie zamieszczane są filmy instruktażowe oraz wskazówki do samodzielnej nauki oryginalnego języka, w jakim powstało Pismo Święte ${ }^{38}$. Interesująca forma prezentacji zachęca wielu do poznawania kontekstu, w jakim powstawała Biblia, tym samym pomagając zrozumieć właściwie stosowane obrazy, metafory oraz teologicznie poprawne przesłanie.

Zdecydowanie mniejsza liczba kont popularyzujących Pismo Święte znajduje się na Instagramie. Do najliczniej obserwowanych należą: „cytaty_biblia” (1249 obserwujących), „mojabiblia” (1159) „pismo_święte_na_dziś” (966) czy „biblijnie” (546). Tutaj także główną formą przekazu treści jest grafika, zawierająca cytaty zaczerpnięte $\mathrm{z}$ ksiąg biblijnych ${ }^{39}$. Wspomniany portal społecznościowy stanowi jednak wciąż ogromny obszar do wykorzystania. Brak jest jakichkolwiek filmów homiletycznych wyjaśniających budzące wątpliwości kwestie. Nieobecne są także tematyczne dyskusje pomiędzy użytkownikami.

\footnotetext{
37 Por. E. Wiszowaty, Technologie informacyjne w warsztacie homilisty, „Poznańskie Studia Teologiczne" 29/1 (2015), s. 225-238.

38 Źródło danych: Facebook,http://bit.ly/sk16-9, http://bit.ly/sk16-10 [dostęp 15.07.2020].

39 Źródło danych: Instagram, http://bit.ly/sk16-11, http://bit.ly/sk16-12 [dostęp 15.07.2020].
} 
Analizując liczbę użytkowników obserwujących poszczególne inicjatywy w odniesieniu do wszystkich członków powyższych mediów społecznościowych (Facebook - $17 \mathrm{mln}$ Polaków, Instagram - 7,3 $\mathrm{mln}^{40}$ ), podane liczby wskazują na niewielki procent osób zainteresowanych treściami biblijnymi. W tej perspektywie jeszcze silniejszym wydaje się wezwanie do zaangażowania chrześcijan w głoszenie Słowa Bożego w rzeczywistości cyfrowej.

b. Aplikacje mobilne, gry

Powszechność użytkowania smartfonów sprawiła, że społeczeństwo ma dostęp do danych niezależnie od miejsca i czasu ${ }^{41}$. Cieszącą się największą popularnością aplikacją mobilną jest „Pismo Święte PL” w wersji pełnej i uproszczonej (ponad $1 \mathrm{mln}$ pobrań $)^{42}$. Kolejne miejsca pod względem liczby użytkowników zajmują „Modlitwa w drodze” (ponad 100 tys.), „Codziennie Biblia wersety” (ponad 100 tys.), „Pismo Święte z komentarzem” opracowane przez Edycję św. Pawła (ponad 50 tys.), „SMS z Nieba” (ponad 50 tys.), „Słowo Boże” (ponad 50 tys.), „Biblia Audio” w formie aplikacji (ponad 50 tys.) „Biblia90dni” (ponad 10 tys.), „Czytania na każdy dzień Mateusz" (ponad 10 tys.) i wiele innych ${ }^{43}$.

Użytkownicy wyżej wymienionych aplikacji, poza dostępem do tekstu ksiąg biblijnych, mają możliwość codziennego otrzymywania przypomnień oraz powiadomień, pomagających w systematyczności czytania Pisma Świętego. Cennymi elementami są także dostęp do komentarzy przygotowanych przez biblistów czy kaznodziejów oraz propozycje modlitw przed spotkaniem ze Słowem Bożym i po nim. Czytania mszalne urozmaicone o materiały wideo, a nawet wprowadzająca w klimat refleksji odpowiednio dobrana muzyka mają na celu zbudowanie jak najlepszej przestrzeni odbioru Słowa. Pozwala to na łatwe korzystanie z wyżej wymienionych form na przykład podczas podróży. Niezwykle interesującą kwestią obecną w aplikacjach są propozycje zaplanowania własnego harmonogramu czytania Biblii czy podręczne zapisywanie osobistych pytań i medytacji.

Coraz częściej spotykamy się z grami opartymi na treściach biblijnych. Jest to swoiste połączenie rozrywki z nauką, przeznaczone głównie dla młodszych użytkowników. Przykładem takiej formy popularyzacji treści biblijnych jest gra przygodowa „Być uczniem Jezusa”. Zadaniem gracza jest dostarczenie listu św. Pawła

\footnotetext{
40 Por. M. Kuchta-Nykiel, Social media w Polsce i na świecie - najnowsze dane, w: http://bit.ly/ sk16-13 [dostęp 15.05.2020].

41 Por. Ł. Lysik, P. Machura, Rola i znaczenie technologii mobilnych w codziennym życiu człowieka XXI wieku, „Media i Społeczeństwo” 4 (2014), s. 15-26; K. Marcyński, Aplikacje mobilne jako nowa forma komunikacji społecznej i religijnej, „Uniwersyteckie Czasopismo Socjologiczne” 15/2 (2016), s. 67-84.

42 Por. R. Aleksandrowicz, E. Repucho, Tekst natchniony w obliczu nowych technologii. Biblia Tysiaclecia w aplikacji na telefon. Perspektywa wydawcy, „Teologia i Człowiek” 36/4 (2016), s. 149-166.

43 Źródło danych: Google Play, http://bit.ly/sk16-14 [dostęp 15.05.2020].
} 
apostoła do jednej z gmin chrześcijańskich, wypełniając po drodze rozmaite zadania. Dzięki takiej grze młody człowiek ma możliwość poznania nie tylko orędzia biblijnego, ale także historii poszczególnych postaci biblijnych oraz ówczesnych zwyczajów w innowacyjny i bardziej przystępny sposób. Na podkreślenie zasługuje wzrastający poziom profesjonalności przygotowywanych materiałów.

Ponadto propozycją dla starszych użytkowników są popularni „Biblionerzy” (ok. 70 tys. użytkowników), zarówno w postaci strony internetowej, jak i aplikacji mobilnej. Wykorzystany przez twórców schemat teleturnieju „Milionerzy” pozwala także na współzawodnictwo w rankingu. To ciesząca się wzrastającym zainteresowaniem forma sprawdzenia stanu swojej wiedzy z zakresu znajomości Pisma Świętego ${ }^{44}$. Prezentowana gra jest przykładem przenikania się kwestii świeckich i religijnych oraz dowodem na umiejętne łączenie przez współczesnych chrześcijan elementów wiary, nauki i rozrywki.

\section{c. Konferencje i rekolekcje online, YouTube}

Do cieszących się popularnością „spotkań” ze Słowem Bożym należą także liczne materiały MP3 lub wideo, publikowane online oraz w serwisie społecznościowym YouTube. Należy wymienić tutaj takie inicjatywy jak seria: „Pismo Święte: Instrukcja Obsługi” (ok. 50 tys. wyświetleń), realizowane przez środowisko Stacja7.pl, codzienne komentarze do czytań - czy to z serii „\#DamyzBogiemRadę" ks. W. Węgrzyniaka (3,46 tys. subskrypcji), czy serii realizowanej przez kanał Dom Józefa (8,19 tys. subskrypcji). Niegasnącą popularnością cieszą się rekolekcje głoszone przez o. A. Szustaka (Langusta na palmie - 676 tys. subskrypcji) oraz serie komentarzy do Słowa Bożego, takie jak „CNN - Słowo na niedzielę”.

Kanał MaskacjuszTV, zasubskrybowany przez 127 tys. użytkowników, regularnie publikuje homilie abpa G. Rysia. Ponadto w serwisie YouTube można znaleźć liczne nagrania głoszenia Pisma Świętego przez kaznodziejów ${ }^{45}$. Wśród nich warto wymienić takie postaci jak ks. P. Pawlukiewicz czy ks. dr hab. R. Skrzypczak. Przez wzgląd na liczne i różnorodne sposoby głoszenia Słowa każdy z poszukujących użytkowników może znaleźć formę najbardziej dogodną dla siebie. Zamieszczanie homilii pozwala także na wielokrotne powracanie do ich treści w dowolnym dla siebie czasie.

Interesującą inicjatywę, mającą na celu popularyzację Pisma Świętego, stanowią utwory muzyczne. Warto wskazać tutaj na utwór ks. J. Bartczaka zatytułowany „Pismo Święte”. Styl przekazu muzycznego, jakim jest hip-hop, to oryginalne wejście na nową drogę docierania do młodzieży. Twórczość ks. Bartczaka publikowaną

\footnotetext{
${ }^{44}$ Por. P. Popiołek, Prolegomena do teologii gier wideo. Ku teologicznej refleksji nad fenomenem gier cyfrowych, w: M. Kłosiński, K. Maj (red.), Dyskursy gier wideo, Kraków 2019, s. 237-266.

${ }^{45}$ Por. A. Makowski, Wykorzystanie technologii audiowizualnych w przepowiadaniu Słowa Bożego, „Biuletyn Edukacji Medialnej” 2 (2017), s. 42-58.
} 
na YouTubie obserwuje 130 tys. subskrybentów ${ }^{46}$. Jest to dowód na to, że cyfrowa społeczność docenia taki sposób popularyzacji treści biblijnych.

Na szczególną uwagę zasługuje także projekt „Biblia Audio”. To największe słuchowisko radiowe w Europie, dostępne na płytach CD, pendrive'ach, YouTubie, ale także w aplikacji mobilnej. W ramach realizacji przedsięwzięcia zaangażowanych zostało niemal pięciuset polskich aktorek i aktorów oraz dziesięć tysięcy statystów $^{47}$. Tła dźwiękowe zostały nagrane w Izraelu, dzięki czemu słuchacz łatwiej może doświadczyć rzeczywistości Ziemi Świętej i jej mieszkańców. W ostatnim czasie powstała także „Biblia Audio Kids” skierowana do dzieci, gdzie lektorami są młodzi aktorzy ${ }^{48}$.

Analizując przedstawioną sytuację, należy podkreślić, iż pomimo występowania różnorodnych form proklamacji Słowa Bożego w środowisku cyfrowym, przestrzeń do jej dalszego zagospodarowania dla urzeczywistniania nakazu misyjnego jest ogromna. Zważywszy na wciąż wzrastający poziom wykorzystywania dorobku cyfryzacji w życiu społecznym należy dążyć do stosowania ich w realizacji celu głoszenia orędzia Bożego. Koniecznym jest także zwrócenie szczególnej uwagi na młodych użytkowników, dla których często jedynym sposobem spotkania z treścią Pisma Świętego jest Internet, będący nieodłączną częścią ich życia. Rzeczywistość cyfrowa powinna być przeniknięta obecnością Słowa Bożego i ducha ewangelicznego.

\section{Zakończenie}

Obowiązek i przywilej docierania z orędziem Słowa Bożego do współczesnego świata realizowany jest na wielu płaszczyznach. Podjęty w artykule temat nie został wyczerpany. Stanowi to punkt wyjścia do dalszego studium i pogłębienia tematu. W związku z dynamicznym rozwojem nowych technologii ta kwestia pozostaje otwarta do dalszych poszukiwań, które autor podejmie w przyszłości.

Analiza podjęta w pierwszym z paragrafów pozwoliła wykazać, iż źródłem obowiązku proklamacji orędzia ewangelicznego jest Stare Przymierze, potwierdzone i wzmocnione nakazem misyjnym Jezusa. Posługa ta opiera się na relacji międzyludzkiej. Aby jednak powstały jej owoce, konieczna jest postawa wrażliwości ze strony odbiorcy. Charakterystyka społeczności rzeczywistości cyfrowej, w tym również współczesnego adresata orędzia ewangelicznego, wskazała na potrzebę wysokiej troski o odpowiednią formę przekazu. Zróżnicowanie społeczeństwa pod względem wielu czynników stanowi duże wyzwanie dla realizacji popularyzacji

\footnotetext{
46 Źródło danych: YouTube.

47 Por. K. Mielnik-Kośmiderski, Biblia Audio-projekt ponadczasowy, w: https://www.przewodnikkatolicki.pl/Archiwum/2017/Przewodnik-Katolicki-36-2017/Kultura/Biblia-Audio-projekt-ponadczasowy [dostęp 5.05.2020].

48 Por. https://www.sklep.bibliaaudio.pl/strona/o-nas [dostęp 5.05.2020].
} 
Pisma Świętego. W rzeczywistości cyfrowej obecne są różnorodne formy proklamacji Słowa Bożego. Mając jednak na względzie całkowitą przestrzeń Internetu, wciąż istnieje potężny obszar do zaaranżowania. Życie chrześcijańskie w naturalny sposób powinno wprowadzać obecność Słowa Bożego i ducha ewangelicznego we wszystkie miejsca, gdzie są obecni wyznawcy Chrystusa.

Wciąż rozwijająca się technologia będzie stwarzać nowe możliwości, które należy wykorzystywać w wypełnianiu misji głoszenia. Należy dołożyć wszelkich starań, aby proponowane formy cechowały się wysoką profesjonalnością, tworząc tym samym właściwy klimat dla słuchania Bożego orędzia ${ }^{49}$. Świadectwo chrześcijan, głoszone słowem i czynem pośród użytkowników rzeczywistości cyfrowej, jest swoistym „zaczynem” do poznania Pisma Świętego i rozwijania wiary. Taka proklamacja Słowa Bożego domaga się kontynuacji w rzeczywistości realnej. Nie może pozostać bez odpowiedzi ze strony człowieka, czego konsekwencją powinna być zmiana myślenia oraz postaw życiowych. Celem podejmowanej popularyzacji jest doprowadzenie do spotkania z Osobowym Słowem - Jezusem oraz pogłębianie tej relacji i wzmacnianie świadomości wiary. W pespektywie postępującej laicyzacji z odwagą należy wkraczać na nowe, współczesne areopagi. Aby owocnie uczestniczyć w tej posłudze, „warunkiem podstawowym odpowiedzialnego za głoszenie Ewangelii w Internecie i poprzez Internet jest bycie Bożym człowiekiem"50.

\section{Streszczenie}

Celem niniejszego artykułu jest próba ukazania obowiązku popularyzacji Pisma Świętego w rzeczywistości cyfrowej, ulegającej stopniowej laicyzacji. Studium oparte na podstawie dokumentów Kościoła, wybranej literatury oraz własnej obserwacji środowiska cyfrowego pozwoliło na ukazanie dotychczasowej realizacji nakazu misyjnego oraz jej aktualnych form. Analiza tematu wykazała konieczność udziału wspólnoty Kościoła w przekazywaniu orędzia biblijnego za pośrednictwem dynamicznie rozwijających się technologii.

Słowa kluczowe: Pismo Święte, rzeczywistość cyfrowa, ewangelizacja, homo medialis.

\section{POPULARIZATION OF HOLY BIBLE IN DIGITAL REALITY. OUTLINE OF ISSUES}

\section{Summary}

The purpose of this article is an attempt to show the duty to popularize Holy Bible in so-called 'digital reality' (including e.g social media), which is prone to secularization.

\footnotetext{
49 Por. M. Chmielewski, I. Durma, R. Kusiak, „Kodeks” social media dla Kościoła katolickiego w Polsce, „Biuletyn Edukacji Medialnej” 1 (2108), s. 146-169.

50 M. Dróżdż, Głosić Dobrą Nowinę na cyfrowych areopagach, dz. cyt., s. 116.
} 
This study, based on various Church documents, selected literature and researchers' own observation of digital environment, allowed to show missionary mandate's implementation and its current forms. The subject analysis showed the necessity of Church community's participation in the proces of passing down of biblical message by using rapidly-developing technologies.

Keywords: Holy Bible, digital reality, evangelization, homo medialis.

\section{Bibliografia}

\section{Nauczanie Kościoła}

Benedykt XVI, Homilia wygłoszona w czasie Mszy Świętej inaugurującej pontyfikat, 24.04.2005, w: https://www.wprost.pl/swiat/75928/homilia-benedykta-xvi.html [dostęp 5.07.2020].

Benedykt XVI, Orędzie na 44. Światowy Dzień Środków Społecznego Przekazu, w: https://opoka.org.pl/biblioteka/W/WP/benedykt_xvi/przemowienia/massmedia2010_24012010.html [dostęp 5.07.2020].

Franciszek, Homilia podczas Mszy św. w kaplicy Domu św. Marty, 6.03.2014, w: https:// opoka.org.pl/biblioteka/W/WP/franciszek_i/homilie/swmarta_06032014.html [dostęp 1.07.2020].

Jan Paweł II, Adhortacja apostolska Christifideles laici (30.12.1988) (= ChL).

Jan Paweł II, Encyklika Redemptoris Missio (7.12.1990) (= RM).

Jan Paweł II, Orędzie na 36. Światowy Dzień Środków Społecznego Przekazu, nr 3, w: www. paulus.org.pl/231,36-sdssp-jan-pawel-ii-2002 [dostęp 1.07.2020].

Paweł VI, Adhortacja apostolska Evangelii nuntiandi (8.12.1975) (= EN).

Sobór Watykański II, Konstytucja dogmatyczna o Kościele Lumen gentium (21.11.1964) (= LG).

Sobór Watykański II, Konstytucja dogmatyczna o Objawieniu Bożym Dei Verbum (18.11.1965) (= DV).

\section{Literatura tematu}

Adamski A., Człowiek zmediatyzowany, „Studia Theologica Varsaviensia” 1 (2017), s. 59-73.

Adamski A., Refleksja teologiczna nad natura Kościoła rzymskokatolickiego a jego wizerunek medialny, w: B. Bogołębska, M. Worsowicz (red.), Dialog wiary z nauką i kultura, Łódź 2013, s. 41-60.

Aleksandrowicz R., Repucho E., Tekst natchniony w obliczu nowych technologii. Biblia Tysiąclecia $w$ aplikacji na telefon. Perspektywa wydawcy, „Teologia i Człowiek” 36/4 (2016), s. 149-166.

Andrzejewska A., Bednarek J., Ćmiel S. (red.), Człowiek w świecie rzeczywistym i wirtualnym, Józefów 2013.

Bednarz M., Powszechność zbawienia w świetle Nowego Testamentu, w: S. Budzik, Z. Kijas (red.), Uniwersalizm chrześcijaństwa a pluralizm religii, Tarnów 2000, s. 31-51.

Bokwa I., Magisterium Kościoła o powszechnej nadziei zbawienia, „Studia Theologica Varsaviensia" 30 (1992) 2, s. 165-171. 
Bosak P.C., Paweł, w: tenże, Leksykon wszystkich postaci biblijnych, Kraków 2015, s. 1180-1197. Chmielewski M., Durma I., Kusiak R., „Kodeks” social media dla Kościoła katolickiego $w$ Polsce, „Biuletyn Edukacji Medialnej” 1 (2108), s. 146-169.

Daniélou J., Święci poganie Starego Testamentu. Pisma wybrane, Kraków 2013.

Domaszk A., Środki komunikacji społecznej w nauczaniu Kościoła i misji ewangelizacyjnej, „Seminare” 34 (2013), s. 81-95.

Dróżdż M., Duchowość w sieci, w: https://currenda.diecezja.tarnow.pl/archiwum/2007/01/ art-18.php [dostęp 5.05.2020].

Dróżdż M., Głosić Dobrą Nowinę na cyfrowych areopagach, w: M. Legan (red.), Bramy prawdy i wiary. Benedykt XVI o mediach, Kraków 2016, s. 111-126.

Fołtyn D., Człowiek wobec mediów. Media wobec człowieka, „Zeszyty Formacji Katechetów” 9 (2020), s. 9-18.

Goban-Klas T., Sienkiewicz P., Społeczeństwo informacyjne: szanse, zagrożenia, wyzwania, Kraków 1999.

Gołębiewski M., Objawienie Boga w Starym Testamencie, „Studia Theologica Varsaviensia” 23/2 (1985), s. 19-43.

IMAS International, Raport z badania „Jak czytamy Pismo święte?”, Wrocław 2018.

Instytut Statystyki Kościoła Katolickiego SAC, Annuarium Statisticum Ecclesiae in Polonia, Warszawa 2020.

Karczewski M., Niektóre sposoby medialnego „wyjaśniania” Biblii, „Studia Elbląskie” 9 (2008), s. 89-100.

Kloch J., Wypłynąć na głębię: stosowanie technologii informatycznych i Internetu w Kościele w myśli Jana Pawła II, „Studia Elbląskie” 7 (2006), s. 239-245.

Kopiczko T., Środki społecznego przekazu pomoca $w$ prowadzeniu do wiary, „Studia Katechetyczne" 10 (2014), s. 163-173.

Kubicka D., Rozwój człowieka w zmediatyzowanym świecie, w: M. Turska-Kielar (red.), Studia nad rozwojem i wychowaniem: $w$ osiemdziesiąta rocznice powstania Zakładu Psychologii Rozwojowej i Wychowawczej na Uniwersytecie Jagiellońskim, Kraków 2009, s. 77-86.

Kuchta-Nykiel M., Social media w Polsce i na świecie - najnowsze dane, w: http://socialpress.pl/2020/02/social-media-w-polsce-i-na-swiecie-najnowsze-dane/amp [dostęp 15.05.2020].

Kwiatkowski D., Głoszenie Słowa Bożego misja Kościoła w świecie na podstawie adhortacji apostolskiej Benedykta XVI Verbum Domini, „Teologia Praktyczna” 17 (2016), s. 93-106.

Lepa A., Ewangelizować areopag mediów, „Studia Warmińskie” 39 (2002), s. 333-345.

Lysik Ł., Machura P., Rola i znaczenie technologii mobilnych w codziennym życiu człowieka XXI wieku, „Media i Społeczeństwo” 4 (2014), s. 15-26.

Makowski A., Wykorzystanie technologii audiowizualnych w przepowiadaniu Słowa Bożego, „Biuletyn Edukacji Medialnej” 2 (2017), s. 42-58.

Marcyński K., Aplikacje mobilne jako nowa forma komunikacji społecznej i religijnej, „Uniwersyteckie Czasopismo Socjologiczne” 15/2 (2016), s. 67-84. 
Mariański J., Praktyki religijne w Polsce - ciagłość i zmiana, „Roczniki Nauk Społecznych” 2/38 (2010), s. 55- 86.

Mielnik-Kośmiderski K., Biblia Audio - projekt ponadczasowy, w: https://www.przewodnik-katolicki.pl/Archiwum/2017/Przewodnik-Katolicki-36-2017/Kultura/Biblia-Audioprojekt-ponadczasowy [dostęp 5.05.2020].

Misztal W., Cyberprzestrzeń i mass media sprzymierzeńcem duchowości?, „Analecta Cracoviensia" 44 (2012), s. 179-190.

Napiórkowski A., Współczesny sekularyzm a teologia sekularyzacji jako wyzwania dla wiary, „Teologia Praktyczna” 14 (2013), s. 17-39.

Nawracała T., Bóg kieruje słowo do Abrahama. Możliwości poznania drugiej Osoby boskiej w Starym Testamencie, „Studia Theologica Varsaviensia” 2/51 (2013), s. 211-229.

Nogowski J.M., Duszpasterstwo w Polsce wobec mass mediów, „Civitas et Lex” 3 (2016) 11, s. 7-14.

Ostafiński W., Orędzie głoszone przez Jezusa Chrystusa, w: H. Sławiński (red.), Głosimy Pana Jezusa Chrystusa. Treść przepowiadania, Kraków 2017, s. 67-86.

Pawson D., Klucz do Biblii, Warszawa 2016, s. 475-478.

Peszko K., Popularność mediów społecznościowych wśród różnych generacji, „Marketing i Zarządzanie" 4/45 (2016), s. 361-370.

Popiołek P., Prolegomena do teologii gier wideo. Ku teologicznej refleksji nad fenomenem gier cyfrowych, w: M. Kłosiński, K. Maj (red.), Dyskursy gier wideo, Kraków 2019, s. 237-266.

Prauzner T., Wpływ nowoczesnych mass mediów na osobowość człowieka, „EdukacjaTechnika-Informatyka” 1 (2010) 2, s. 46-50.

Stern D.H., Komentarz żydowski do Nowego Testamentu, Warszawa 2017, s. 448nn. Szymik S., Biblia o powszechności zbawienia, „Forum Teologiczne” 5 (2004), s. 7-21.

Węgrzyn-Jonek E., Rozważania o wychowaniu. W poszukiwaniu teoretycznych podstaw koncepcji wychowawczej szkoły, Warszawa 2014.

Wiszowaty E., Technologie informacyjne $w$ warsztacie homilisty, „Poznańskie Studia Teologiczne" 29/1 (2015), s. 225-238.

\section{$\mathrm{O}$ autorze}

Paulina OKŁA - studentka teologii ze specjalnością nauczycielsko-katechetyczną. Nauczyciel religii w szkole podstawowej. Zakres swoich zainteresowań badawczych koncentruje wokół tematów związanych z biblistyką, judaizmem, katechetyką i muzyką. 